\title{
High-temperature Oxidation of Hot-dip Aluminized 2.25Cr-1Mo Steel
}

\author{
Muhammad Ali Abro', Junhee Hahn², and Dong Bok Lee ${ }^{3, *}$ \\ ${ }^{l}$ Department of Mechanical Engineering, Mehran University of Engineering and Technology, SZAB Campus, \\ Khairpur Mir's 66020, Pakistan \\ ${ }^{2}$ Center for Energy Materials Metrology, Korea Research Institute of Standards and Science, Daejon 34113, Republic of Korea \\ ${ }^{3}$ School of Advanced Materials Science \& Engineering, Sungkyunkwan University, Suwon 16419, Republic of Korea
}

\begin{abstract}
When 2.25Cr-1Mo steel was hot-dip aluminized, a coating consisting of (Al-rich topcoat)/( $\mathrm{Al}_{13} \mathrm{Fe}_{4}$ layer $/\left(\mathrm{Al}_{5} \mathrm{Fe}_{2}\right.$ layer $)$ formed. With increment of oxidation temperature, the transform of $\mathrm{Al} \rightarrow \mathrm{Al}_{13} \mathrm{Fe}_{4} \rightarrow \mathrm{Al}_{5} \mathrm{Fe}_{2} \rightarrow \mathrm{AlFe} \rightarrow \mathrm{AlFe}_{3} \rightarrow \alpha-\mathrm{Fe}(\mathrm{Al}) \rightarrow \alpha$-Fe occurred through interdiffusion between the coating and the substrate as follows. The oxidation at $700{ }^{\circ} \mathrm{C}$ changed the coating to $\left(\mathrm{a}-\mathrm{Al}_{2} \mathrm{O}_{3}\right.$ scale)/( $\left(\mathrm{a}-\mathrm{Al}_{2} \mathrm{O}_{3}, \mathrm{Al}_{13} \mathrm{Fe}_{4}\right.$, $\left.\mathrm{Al}_{5} \mathrm{Fe}_{2}\right)$-mixed layer $) /\left(\mathrm{Al}_{5} \mathrm{Fe}_{2}\right.$ layer $) /(\mathrm{AlFe}$ layer $) /\left(\mathrm{AlFe}_{3}\right.$ layer $) /(\alpha-\mathrm{Fe}(\mathrm{Al})$ layer $)$. The oxidation at $800{ }^{\circ} \mathrm{C}$ changed the coating to (a- $\mathrm{Al}_{2} \mathrm{O}_{3}$ scale)/((a- $\left.\mathrm{Al}_{2} \mathrm{O}_{3}, \mathrm{Al}_{5} \mathrm{Fe}_{2}\right)$-mixed layer $) /\left(\mathrm{Al}_{5} \mathrm{Fe}_{2}\right.$ layer $) /(\mathrm{AlFe}$ layer $) /\left(\mathrm{AlFe}{ }_{3}\right.$ layer $) /(\alpha-\mathrm{Fe}(\mathrm{Al})$ layer). The oxidation at $900{ }^{\circ} \mathrm{C}$ changed the coating to $\left(\alpha-\mathrm{Al}_{2} \mathrm{O}_{3}\right.$ scale $) /\left(\left(\alpha-\mathrm{Al}_{2} \mathrm{O}_{3}, \mathrm{AlFe}\right)\right.$-mixed layer $) /(\mathrm{AlFe}$ layer $) /\left(\mathrm{AlFe}_{3}\right.$ layer $) /(\alpha-\mathrm{Fe}(\mathrm{Al})$ layer$)$. The oxidation at $1000{ }^{\circ} \mathrm{C}$ changed the coating to $\left(\left(\alpha-\mathrm{Al}_{2} \mathrm{O}_{3}, \mathrm{Fe}_{2} \mathrm{O}_{3}\right)-\right.$ mixed layer $) /\left(\mathrm{AlFe}_{3}\right.$ layer $) /(\alpha-\mathrm{Fe}(\mathrm{Al})$ layer $)$.
\end{abstract}

(Received January 8, 2018; Accepted February 19, 2018)

Keywords: hot dipping, aluminizing, P22 steel, oxidation

\section{INTRODUCTION}

Developing cost-effective surface modification techniques with enhanced oxidation resistance without sacrificing mechanical properties is attracting enormous interest in power generation, petrochemical, and automotive industries. Hot-dip aluminizing is a popular, highly efficient, easily reproducible, and cost-effective technique that can be applied on substrates of arbitrary configuration [1]. It provides superior hightemperature oxidation resistance by forming highly protective $\alpha-\mathrm{Al}_{2} \mathrm{O}_{3}$ surface scale in oxidative environments [2]. Interdiffusion between $\mathrm{Al}$ atoms from the molten $\mathrm{Al}$ bath and $\mathrm{Fe}$ atoms from the steel substrate forms a highly adherent coating consisting of Al-rich topcoat and the intermetallic layer consisting of outer minor $\mathrm{Al}_{13} \mathrm{Fe}_{4}$ layer and inner major $\mathrm{Al}_{5} \mathrm{Fe}_{2}$ layer [3-5]. Hotdip aluminizing has been applied on $\mathrm{Fe}-\mathrm{Cr}$ steels such as $2.25 \mathrm{Cr}-1 \mathrm{Mo}$ steel (ASTM P22) [5], 5.2Cr-1.2Mo$0.9 \mathrm{~V}$ steel (AISI H13) [6], 9Cr-1.4W steel (CLAM)

*Corresponding Author: Dong Bok Lee [Tel: +82-31-290-7355, E-mail: dlee@skku.ac.kr] Copyright (C) The Korean Institute of Metals and Materials
[7], 9Cr-1Mo steel (P91) [8-10], 12Cr steel [11], and stainless steels [12]. In case of $2.25 \mathrm{Cr}-1 \mathrm{Mo}$ steel that was hot-dip aluminized in pure $\mathrm{Al}$ molten bath at $700{ }^{\circ} \mathrm{C}$ for $3 \mathrm{~min}$, a pure $\mathrm{Al}$ topcoat having needlelike, scattered $\mathrm{FeAl}_{3}$ islands, an outer minor $\mathrm{FeAl}_{3}$ layer dissolved with 0.5 at $\% \mathrm{Cr}$, and an inner major $\mathrm{Fe}_{2} \mathrm{Al}_{5}$ layer dissolved with 0.8 at $\% \mathrm{Cr}$ formed [5]. Chromium in steels retarded the interdiffusion between steels and aluminum, resulting in decrement of the intermetallic layer thickness and flattening of the intermetallic layer/steel interface [5]. However, little information is available in literature concerning the oxidation behavior of hot-dip aluminized $2.25 \mathrm{Cr}-1 \mathrm{Mo}$ steels, although such information is of crucial importance for high-temperature applications. Thickness, morphology, and composition of coating layers are affected by compositions of the molten $\mathrm{Al}$ bath and substrate, hot-dipping parameters, and heat-treatment conditions including oxidation. Therefore, the objective of this study was to investigate microstructural transition of hot-dip aluminized $2.25 \mathrm{Cr}-1 \mathrm{Mo}$ steel during oxidation at $700-1000{ }^{\circ} \mathrm{C}$ for $20 \mathrm{~h}$ utilizing various analytical equipments. 

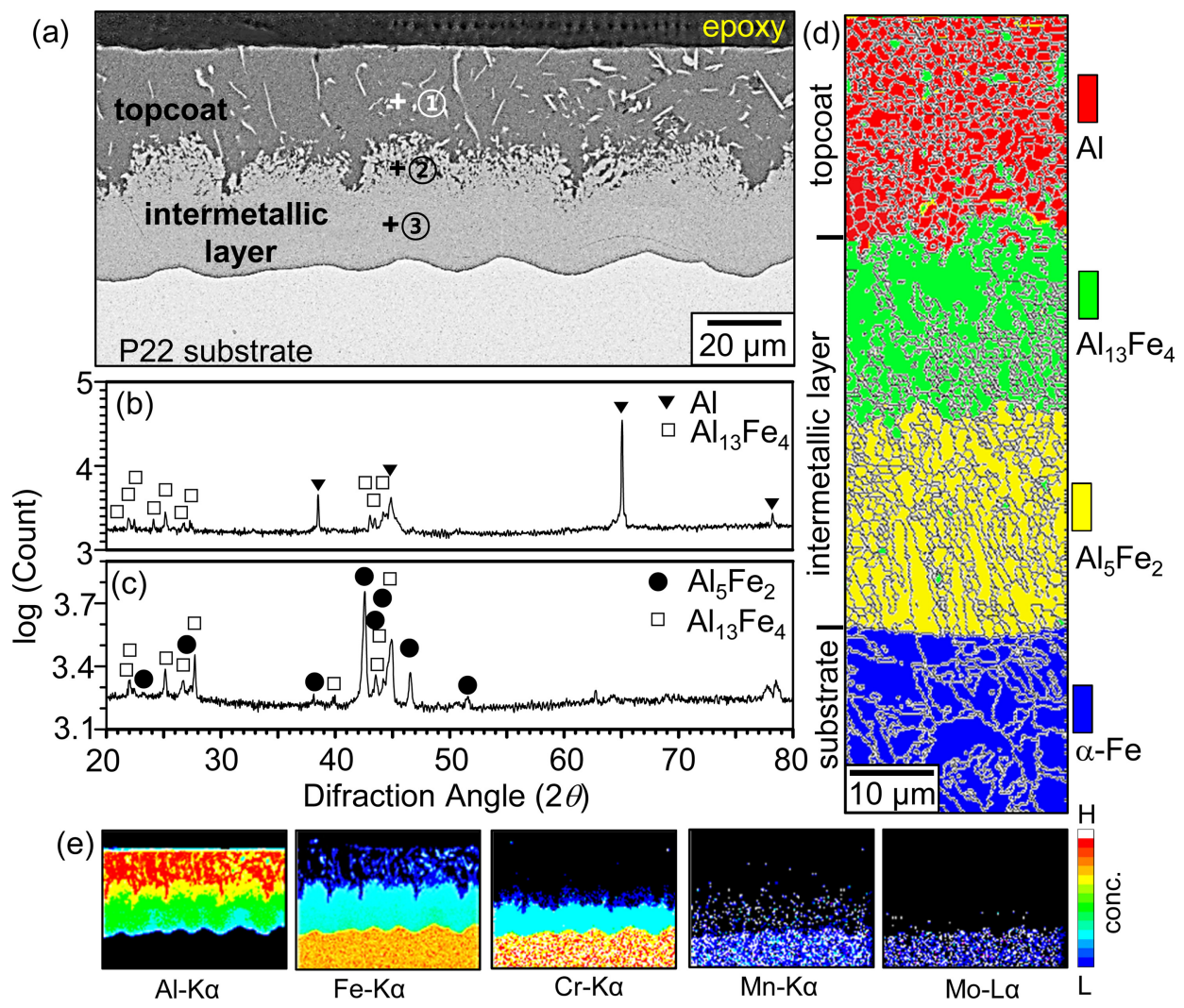

Fig. 1. Hot-dip aluminized P22 steel. (a) EPMA back-scattered electron (BSE) cross-sectional image (unetched), (b) XRD pattern of coating (as-hot-dipped condition), (c) XRD pattern after grinding off the coating surface, (d) EBSD phase map, (e) EPMA maps of (a).

\section{EXPERIMENT DETAILS}

ASTM P22 ferritic steel plate (Fe-2.25Cr-1Mo$0.45 \mathrm{Mn}-0.3 \mathrm{Si}-0.12 \mathrm{C}$ in $\mathrm{wt} \%$ ) was cut to $80 \times 20 \times 2 \mathrm{~mm}^{3}$ sized coupons, ground with 1000 grit $\mathrm{SiC}$ paper, ultrasonically cleaned in acetone and alcohol, and dipped in the molten $\mathrm{Al}$ bath at $800{ }^{\circ} \mathrm{C}$ for $5 \mathrm{~min}$, on top of which a solid flux $\left(\mathrm{KCl}+\mathrm{NaCl}+\mathrm{AlF}_{3}\right.$ in 2:2:1 in ratio) was spread to protect the bath from oxidation. These hot-dip aluminized steel coupons were pulled out, cooled to room temperature in air, cleaned with $5 \mathrm{vol} \% \mathrm{HNO}_{3}$ solution to remove any flux on the surface, and rinsed with water. Oxidation test of hot-dip aluminized steel samples was performed at $700,800,900$, and $1000^{\circ} \mathrm{C}$ for $20 \mathrm{~h}$ in air using a furnace. Aluminized/oxidized samples were inspected using an optical microscope (OM), a high power Xray diffractometer (XRD) with $\mathrm{Cu}-\mathrm{K} \alpha$ radiation at 40 $\mathrm{kV}$ and $100 \mathrm{~mA}$, a field-emission scanning electron microscope (SEM) equipped with an energy-dispersive spectroscope (EDS), an electron probe microanalyzer (EPMA), and electron backscatter diffraction (EBSD) technique. Cross-sections of the aluminized layer and the steel substrate were examined by etching with the Keller's reagent and Vilella's reagent, respectively. Hereafter, all compositions denoted are atomic percentages (at $\%)$ unless otherwise specified.

\section{RESULTS AND DISCUSSION}

Figure 1 shows EPMA/XRD/EBSD results of hot-dip aluminized P22 steel. Hot-dipping formed $\sim 30 \mu \mathrm{m}$-thick topcoat and $\sim 35 \mu \mathrm{m}$-thick intermetallic layer on the steel substrate (Fig. 1(a)). Vertical axes of Figs. 1(b) and 1(c) are plotted in logarithmic scale in order to show minor peaks. In Fig. 1(b), strong $\mathrm{Al}$ peaks and weak $\mathrm{Al}_{13} \mathrm{Fe}_{4}$ peaks were detected, indicating that a small amount of $\mathrm{Al}_{13} \mathrm{Fe}_{4}$ precipitates was present in 

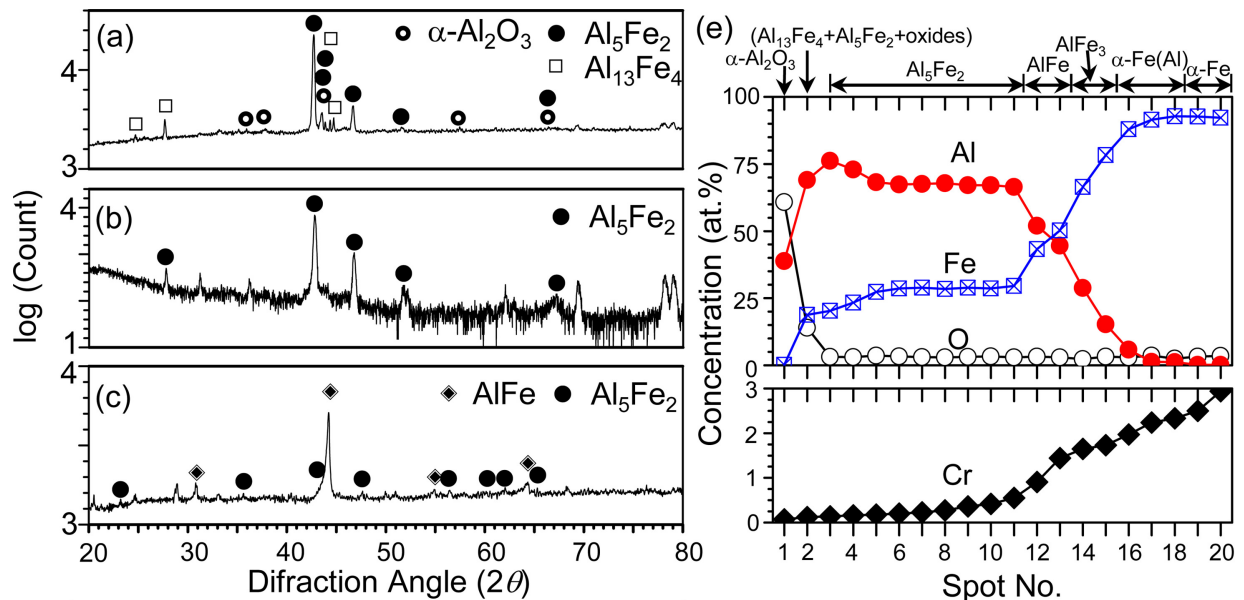

(d)
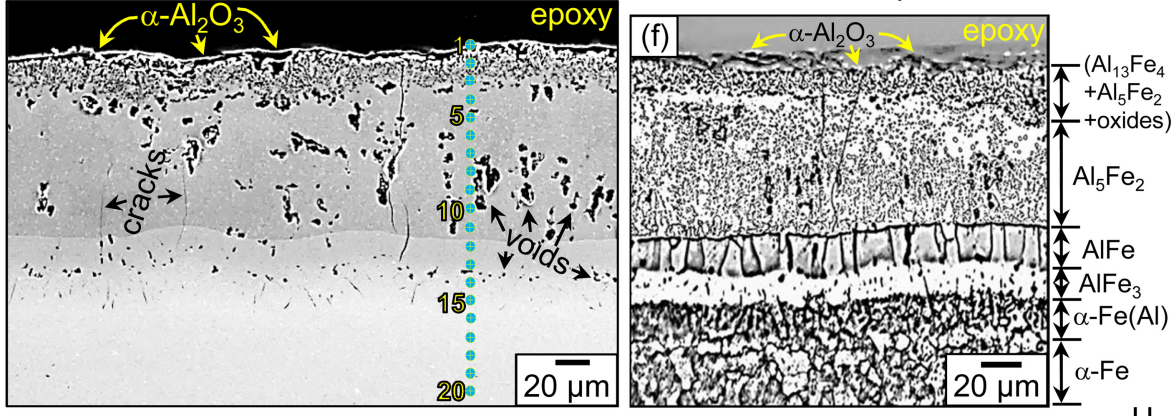

(g)

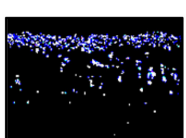

O-Ka

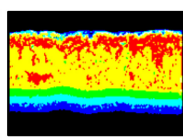

Al-Ka

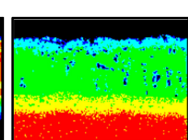

Fe-Ka

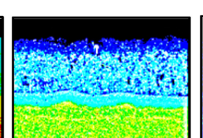

Cr-Ka

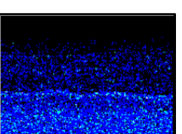

$\mathrm{Mn}-\mathrm{Ka}$

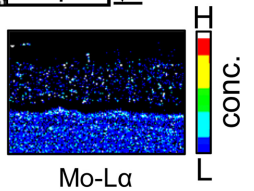

Fig. 2. Hot-dip aluminized $\mathrm{P} 22$ steel after oxidation at $700{ }^{\circ} \mathrm{C}$ for $20 \mathrm{~h}$. (a) XRD pattern before grinding the surface, (b) XRD pattern after first grinding, (c) XRD pattern after second grinding, (d) EPMA cross-sectional secondary electron (SE) image (unetched), (e) SEM-EDS concentration profiles of spots 1-20 marked in (d), (f) OM image (etched), (g) EPMA maps of (d).

the Al-rich topcoat. When this topcoat was ground off manually using an emery paper, weak $\mathrm{Al}_{5} \mathrm{Fe}_{2}$ peaks and strong $\mathrm{Al}_{13} \mathrm{Fe}_{4}$ peaks appeared [9] (Fig. 1(c)). $\mathrm{Al}_{13} \mathrm{Fe}_{4}$ and $\mathrm{Al}_{5} \mathrm{Fe}_{2}$ peaks came from the upper and lower part of the intermetallic layer, respectively (Fig. 1(d)). $\mathrm{Al}_{8} \mathrm{Cr}_{5}$ that was detected to a small amount in hot-dip aluminized steels containing more than 9 wt $\% \mathrm{Cr}[8,13]$ was not detected in this study. In Fig. 1(d), $\mathrm{Al}_{13} \mathrm{Fe}_{4}$ precipitates scattered in the Al-rich topcoat [14]. Most grains in the coating were small and equiaxed. Some columnar grains in the lower part of the $\mathrm{Al}_{5} \mathrm{Fe}_{2}$ layer were aligned along the interdiffusion direction of $\mathrm{Al}$ and substrate elements [8,15]. EDSanalyzed compositions (\%) were 95.6Al-4.3Fe-0.1Mn for spot (1) (viz. Al-rich topcoat), 75.9Al-23.3Fe-0.6Cr$0.2 \mathrm{Mn}$ for spot (2) (viz. $\mathrm{Al}_{13} \mathrm{Fe}_{4}$ layer), and 69.3Al-
28.1Fe-2.2Cr-0.3Mn-0.1Mo for spot (3) (viz. $\mathrm{Al}_{5} \mathrm{Fe}_{2}$ layer) (Fig. 1(a)). This indicated that $\mathrm{Fe}, \mathrm{Cr}, \mathrm{Mn}$, and Mo diffused outwardly toward the surface while Al diffused inwardly across the topcoat according to the concentration gradient. Whitish flakes in the topcoat shown in Fig. 1(a) were $\mathrm{Al}_{13} \mathrm{Fe}_{4}$ islands embedded in Al grains [5] according to Fig. 1(e). The topcoat retained a small amount of dissolved $\mathrm{Mn}$. It was almost free from $\mathrm{Cr}$ and Mo (Fig. 1(e)). Maps of $\mathrm{Cr}$ and Mo indicated that $\mathrm{Cr}$ and Mo dissolved more in the $\mathrm{Al}_{5} \mathrm{Fe}_{2}$ layer than the $\mathrm{Al}_{13} \mathrm{Fe}_{4}$ layer because the former was closer to the steel substrate than the latter.

The hot-dip aluminized P22 steel was oxidized at $700{ }^{\circ} \mathrm{C}$ for $20 \mathrm{~h}$ and successively ground off from the surface on the emery paper. X-ray analysis results are shown in Figs. 2(a-c). In Fig. 2(a), strong $\mathrm{Al}_{5} \mathrm{Fe}_{2}$ 
peaks as well as weak $\alpha-\mathrm{Al}_{2} \mathrm{O}_{3}$ and $\mathrm{Al}_{13} \mathrm{Fe}_{4}$ peaks were detected at the surface. Such result implied that the Al-rich topcoat transformed to either $\alpha-\mathrm{Al}_{2} \mathrm{O}_{3}$ or $\mathrm{Al}_{5} \mathrm{Fe}_{2}$ plus a small amount of $\mathrm{Al}_{13} \mathrm{Fe}_{4}$. Such oxidation and phase transformation would occur fast because the test temperature was above the melting point of $\mathrm{Al}$ $\left(660^{\circ} \mathrm{C}\right)$. Below the coating surface, $\mathrm{Al}_{5} \mathrm{Fe}_{2}$ peaks were mainly detected (Fig. 2(b)). Further grinding revealed strong $\mathrm{AlFe}$ and weak $\mathrm{Al}_{5} \mathrm{Fe}_{2}$ peaks (Fig. 2(c)). These XRD results indicated that the hot-dipped coating transformed to $\left(\alpha-\mathrm{Al}_{2} \mathrm{O}_{3}\right.$ scale $) /\left(\right.$ mostly $\mathrm{Al}_{5} \mathrm{Fe}_{2}$ plus a small amount of $\left.\mathrm{Al}_{13} \mathrm{Fe}_{4}\right) /\left(\mathrm{Al}_{5} \mathrm{Fe}_{2}\right.$ layer $) /(\mathrm{AlFe}$ layer) from the surface. Depending on investigators, when hot-dipped $\left(\mathrm{Al}_{13} \mathrm{Fe}_{4}\right.$ layer $) /\left(\mathrm{Al}_{5} \mathrm{Fe}_{2}\right.$ layer $)$ were oxidized at $700-760{ }^{\circ} \mathrm{C}$ for $15-30 \mathrm{~h}$, they transformed to $\left(\mathrm{Al}_{2} \mathrm{Fe}\right.$ layer $) /(\mathrm{AlFe}$ layer) [7] or ( $\mathrm{AlFe}$ layer $) /\left(\mathrm{AlFe}_{3}\right.$ layer) [16]. Unetched EPMA image (Fig. 2(d)), SEMEDS analyzed composition profiles (Fig. 2(e)), and etched OM image (Fig. 2(f)) clarified the spots marked in Fig. 2(d) as follows: Spot $1=(\sim 2 \mu \mathrm{m}-$ thick $\alpha-\mathrm{Al}_{2} \mathrm{O}_{3}$ scale); Spots $2-3=(\sim 13 \mu \mathrm{m}$-thick, $(\alpha-$ $\mathrm{Al}_{2} \mathrm{O}_{3}, \mathrm{Al}_{5} \mathrm{Fe}_{2}$ )-intermixture having a small amount of $\mathrm{Al}_{13} \mathrm{Fe}_{4}$ ) (see Fig. 2(a)). Dark spots around spots 2-3 were $\alpha-\mathrm{Al}_{2} \mathrm{O}_{3}$ particles (Fig. 2(d)). Since spots 2-3 originally belonged to Al-rich topcoat, their Al concentration was high as shown in the Al map of Fig. 2(g). Spots 3-11 $=\left(\sim 80 \mu \mathrm{m}\right.$-thick $\mathrm{Al}_{5} \mathrm{Fe}_{2}$ layer) (see Fig. 2(b)). Spots $12-13=(\sim 20 \mu \mathrm{m}$-thick AlFe layer $)$ (see Fig. 2(c)). Spots $14-15=\left(\sim 20 \mu \mathrm{m}\right.$-thick $\mathrm{AlFe}_{3}$ layer). Spots $16-18=(\sim 30 \mu \mathrm{m}$-thick $\alpha$-Fe(Al) layer $)$. Spots $19-20=\alpha-\mathrm{Fe}$ substrate. The $\alpha-\mathrm{Fe}(\mathrm{Al})$ phase can form because more than $10 \% \mathrm{Al}$ dissolves in $\alpha-\mathrm{Fe}$ at room temperature according to the Al-Fe phase diagram. Grains in the AlFe layer were columnar while overlying $\mathrm{Al}_{13} \mathrm{Fe}_{4}$ and $\mathrm{Al}_{5} \mathrm{Fe}_{2}$ grains were fine (Fig. 2(f)). The $\alpha-\mathrm{Al}_{2} \mathrm{O}_{3}$ scale shown in Fig. 2(d) was loosely adherent and somewhat convoluted owing to its mismatch in thermal expansion coefficients with underlying $\mathrm{Al}-\mathrm{Fe}$ phases. Thermal expansion coefficient is $8 \times 10^{-6} \mathrm{~K}^{-1}$ for $\alpha-\mathrm{Al}_{2} \mathrm{O}_{3}[17], 18.94 \times 10^{-6} \mathrm{~K}^{-1}$ for $\mathrm{Fe}_{2} \mathrm{Al}_{5}$, and $19.68 \times 10^{-6} \mathrm{~K}^{-1}$ for $\mathrm{FeAl}_{3}$ [18]. The coating shown in Fig. 2(d) cracked vertically owing to difference in thermal expansion coefficients [19] and volume shrinkage arisen owing to transformation of (high Al)-Fe phases to (low Al)-Fe phases during oxidation. Density $\left(\mathrm{g} / \mathrm{cm}^{3}\right)$ is 2.7 for $\mathrm{Al}, 3.84$ for $\mathrm{Al}_{13} \mathrm{Fe}_{4}, 3.96$ for $\mathrm{Al}_{5} \mathrm{Fe}_{2}$, and 5.666 for $\mathrm{AlFe}$. The brittleness of $\mathrm{Al}_{13} \mathrm{Fe}_{4}$ and $\mathrm{Al}_{5} \mathrm{Fe}_{2}$ additionally facilitated cracking [6,20,21]. In order to avoid cracks, many attempts have been made as follows. (1) Replace brittle $\mathrm{Al}_{13} \mathrm{Fe}_{4}$ and $\mathrm{Al}_{5} \mathrm{Fe}_{2}$ with ductile $\mathrm{AlFe}$ and $\mathrm{AlFe}_{3}$ through laser melting [8,22], heat treatment $[9,13,16,23]$, and oxidation [7]. (2) Add $\mathrm{Si}$ in the molten $\mathrm{Al}$ bath to suppress the growth of $\mathrm{Al}_{5} \mathrm{Fe}_{2}$ with $30 \%$ vacancies along [001] growth direction, leading to reduction of thickness of the intermetallic layer [3,15], (3) Add alloy elements and second-phase particles to reduce the thickness of the intermetallic layer [6], (4) Seal cracks by impregnating the coating with $\mathrm{H}_{3} \mathrm{PO}_{4}$ solution [19]. The unequal inward diffusion of $\mathrm{Al}$ and oxygen as well as outward diffusion of substrate elements produced Kirkendall voids at spots 3-15 (Fig. 2(d)). Voids in the $\mathrm{Al}_{5} \mathrm{Fe}_{2}$ layer were coarser than those in the $\mathrm{AlFe}$ or $\mathrm{AlFe}_{3}$ layer because substrate elements diffused outwardly more in the $\mathrm{Al}_{5} \mathrm{Fe}_{2}$ layer (Fig. 2(d)). The insufficient adherence of $\alpha-\mathrm{Al}_{2} \mathrm{O}_{3}$ scale, voids, and cracks led to the formation oxide particles down to spot 15 (see Fig. 2(d) and oxygen map shown in Fig. 2(g)). All Al-Fe phases denoted in Fig. 2(f) were dissolved with substrate alloying elements such as $\mathrm{Cr}$, Mo, and $\mathrm{Mn}$, which diffused outwardly according to concentration gradients (Fig. 2(g)).

The hot-dip aluminized P22 steel that oxidized at $800{ }^{\circ} \mathrm{C}$ for $20 \mathrm{~h}$ was successively grinded off from the surface. X-ray results are shown in Figs. 3(a-d). Strong $\mathrm{Al}_{5} \mathrm{Fe}_{2}$ peaks and weak $\alpha-\mathrm{Al}_{2} \mathrm{O}_{3}$ peaks were detected at the surface (Fig. 3(a)). In this figure, weak $\mathrm{Al}_{13} \mathrm{Fe}_{4}$ peaks detected in Fig. 2(a) were absent owing to the enhanced interdiffusion at $800{ }^{\circ} \mathrm{C}$. Since the formed $\alpha-\mathrm{Al}_{2} \mathrm{O}_{3}$ scale was thin and loosely adherent, $\alpha-\mathrm{Al}_{2} \mathrm{O}_{3}$ peaks were weak in Fig. 3(a). Strong $\mathrm{Al}_{5} \mathrm{Fe}_{2}, \mathrm{AlFe}$, and $\mathrm{AlFe}_{3}$ peaks were detected in Figs. 3(b), (c), and (d), respectively. Such XRD results indicated the formation of $\alpha-\mathrm{Al}_{2} \mathrm{O}_{3} / \mathrm{Al}_{5} \mathrm{Fe} \mathrm{e}_{2} / \mathrm{AlFe} /$ $\mathrm{AlFe}_{3}$ layers from the surface. The coating was 

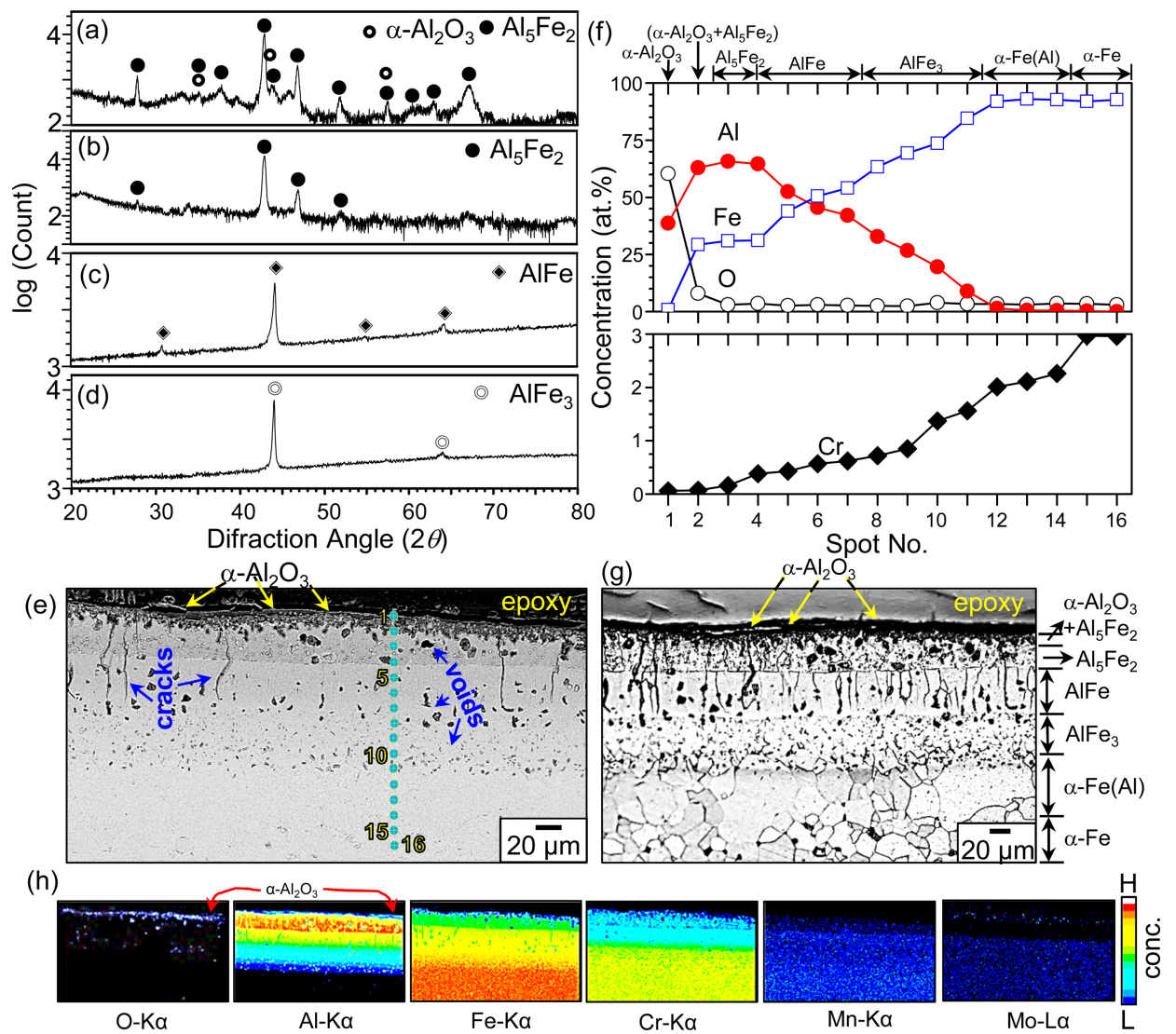

Fig. 3. Hot-dip aluminized $\mathrm{P} 22$ steel after oxidation at $800{ }^{\circ} \mathrm{C}$ for $20 \mathrm{~h}$. (a) XRD pattern before grinding, (b) XRD pattern after first grinding, (c) XRD pattern after second grinding, (d) XRD pattern after third grinding, (e) EPMA cross-sectional SE image (unetched), (f) SEM-EDS concentration profiles of spots 1-15 shown in (e), (g) OM image (etched), (h) EPMA maps of (e).

analyzed in more detail as follows using EPMA/EDS/ OM. In Figs. 3(e-f), spot 1 corresponded to the loosely adherent $\alpha-\mathrm{Al}_{2} \mathrm{O}_{3}$ layer. Spot 2 corresponded to $\alpha-\mathrm{Al}_{2} \mathrm{O}_{3}$ particles in the $\mathrm{Al}_{5} \mathrm{Fe}_{2}$ layer. $\alpha-\mathrm{Al}_{2} \mathrm{O}_{3}$ that grew extremely slowly came out as dark spots in Figs. 3(e) and 3(g). Spots 3-4 corresponded to the $\mathrm{Al}_{5} \mathrm{Fe}_{2}$ layer consisting of fine grains (Figs. 3(b, e-g)). Spots 4-7 corresponded to the AlFe layer consisting of columnar grains whose growth was dominated by the outward transport of $\mathrm{Fe}$ and inward migration of Al (Figs. 3(c, e-g)). Figures 3(d) and 3(e-g) indicated that spots 8-11 corresponded to the $\mathrm{AlFe}_{3}$ layer. This layer was hardly etched because of dissolved $\mathrm{Cr}$ (Figs. 3(f) and (h)). Spots 12-14 and 15-16 corresponded to the $\alpha-\mathrm{Fe}(\mathrm{Al})$ layer and the $\alpha-\mathrm{Fe}$ substrate, respectively (Figs. 3(e-h)). Grains of $\alpha-\mathrm{Fe}(\mathrm{Al})$ which were coarser than those of $\alpha-\mathrm{Fe}$ were dissolved with $\mathrm{Cr}$ (Figs. 3(f) and (h)). The $\mathrm{Al}$ concentration in the $\alpha-\mathrm{Fe}(\mathrm{Al})$ layer decreased from $1.4 \%$ at spot 12 to $0.4 \%$ at spot 14 (Fig. 3(f)) while the $\alpha$-Fe substrate was virtually Alfree. Vertical cracks, which developed owing to phase transformation of Al-Fe phases and mismatch in thermal expansion coefficients among Al-Fe phases, propagated down to the AlFe layer with columnar grains (Figs. 3(e) and 3(g)). Oxygen diffused inwardly during oxidation. Its concentration decreased from $8 \%$ at spot 2 to $3 \%$ at spot 16 (Fig. 3(f)). Internal $\alpha$ $\mathrm{Al}_{2} \mathrm{O}_{3}$ particles, voids, and cracks came out dark in Fig. 3(e). The closer to the surface, the bigger voids became because substrate elements diffused out more. Oxides also became bigger because more oxygen and Al were available. The distribution of oxides and elements of concern is displayed in Fig. 3(h). Results obtained from Fig. 3 may be summarized as follows. Oxidation led to the formation of $\sim 2 \mu$ m-thick $\alpha-\mathrm{Al}_{2} \mathrm{O}_{3}$ surface scale, $15 \mu \mathrm{m}$-thick $\left(\mathrm{Al}_{5} \mathrm{Fe}_{2}+\alpha-\mathrm{Al}_{2} \mathrm{O}_{3}\right)$-mixed 


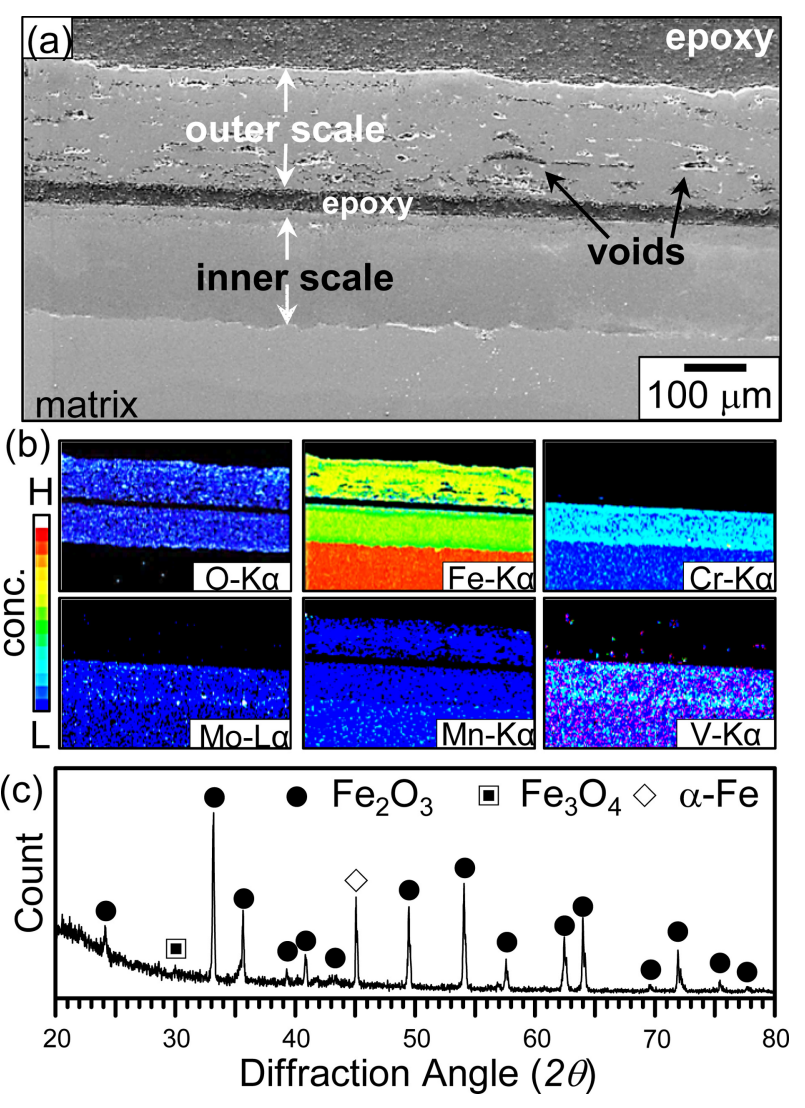

Fig. 4. Uncoated $\mathrm{P} 22$ steel after oxidation at $800^{\circ} \mathrm{C}$ for 20 h. (a) cross-sectional EPMA SE image (unetched), (b) EPMA mappings of (a), (c) XRD pattern taken from the surface.

layer, (20-30) $\mu \mathrm{m}$-thick $\mathrm{Al}_{5} \mathrm{Fe}_{2}$ layer, (40-50) $\mu \mathrm{m}$-thick AlFe layer, (40-50) $\mu$ m-thick $\mathrm{AlFe}_{3}$ layer, and (35-50) $\mu \mathrm{m}$-thick $\alpha$-Fe(Al) layer on the $\alpha$-Fe substrate.

EPMA/XRD results shown in Fig. 4 were obtained from bare P22 steel which was oxidized under the same condition outlined in Fig. 3. Without hot-dipping, $\sim 190 \mu \mathrm{m}$-thick, porous, nonadherent outer oxide scale, and $\sim 190 \mu \mathrm{m}$-thick, somewhat dense, and loosely adherent inner oxide scale formed (Fig. 4(a)). Oxygen migrated easily across the outer scale to form the inner scale (Fig. 4(b)). The outer scale grew primarily by outward diffusion of $\mathrm{Fe}$ and $\mathrm{Mn}$, while the inner scale grew primarily by inward diffusion of oxygen (Fig. 4(b)). The partial spallation of outer and inner oxide scales yielded a strong $\alpha-\mathrm{Fe}$ peak besides strong $\mathrm{Fe}_{2} \mathrm{O}_{3}$ peaks and a weak $\mathrm{Fe}_{3} \mathrm{O}_{4}$ peak in Fig. 4(c). SEM-EDS analysis indicated that the composition of the outer and inner scale was $59 \mathrm{O}-0.95 \mathrm{Mn}-40.05 \mathrm{Fe}$ and $56 \mathrm{O}-0.7 \mathrm{Cr}-0.3 \mathrm{Mn}-43 \mathrm{Fe}(\%)$, respectively, suggesting that the outer and inner scale primarily consisted of $\mathrm{Fe}_{2} \mathrm{O}_{3}$ and $\mathrm{Fe}_{3} \mathrm{O}_{4}$, respectively. Comparison between Fig. 3 and Fig. 4 clearly indicated that hot-dipping significantly improved oxidation resistance.

When hot-dip aluminized P22 steel was oxidized at $900{ }^{\circ} \mathrm{C}$ for $20 \mathrm{~h}$, the $\alpha-\mathrm{Al}_{2} \mathrm{O}_{3}$ surface scale formed on the coating that consisted of the AlFe outer layer and the $\mathrm{AlFe}_{3}$ inner layer [6] as shown in Figs. 5(a-c). In the etched $\mathrm{OM}$ image shown in Fig. 5(d), $\alpha-\mathrm{Al}_{2} \mathrm{O}_{3}$ scale consisting of fine grains, $\mathrm{AlFe}$ layer consisting of short columnar grains, and $\mathrm{AlFe}_{3}$ layer consisting of coarse columnar grains were seen from the surface. In iron aluminides, $\mathrm{Al}$ diffusion is always slightly faster than $\mathrm{Fe}$ diffusion [24] and $\mathrm{Fe}$ diffuses faster in $\mathrm{AlFe}_{3}$ than $\mathrm{FeAl}$ [25]. Hence, $\mathrm{AlFe}_{3}$ grains can grow coarser and more columnar than $\mathrm{AlFe}$ grains as shown in Fig. 5(d). A scratch marker is shown in Fig. 5(d). It was engraved using a knife at the coating surface prior to oxidation. It was covered with a thin $\alpha-\mathrm{Al}_{2} \mathrm{O}_{3}$ surface scale, indicating that outward transport of substrate elements did not occur significantly. Unetched EPMA image, EDS-analyzed concentration profiles, and EPMA maps are shown in Figs. 5(e), 5(f), and 5(g), respectively. Phase transformation of Al (Fig. 1(d); density, $\rho=2.7 \mathrm{~g} / \mathrm{cm}^{3}$ ) through $\mathrm{Al}_{13} \mathrm{Fe}_{4}$ (Fig. 2(e); $\rho=3.84 \mathrm{~g} / \mathrm{cm}^{3}$ ) and $\mathrm{Al}_{5} \mathrm{Fe}_{2}$ (Fig. 3(f); $\rho=3.96 \mathrm{~g} / \mathrm{cm}^{3}$ ) to AlFe (Fig. 5(f); $\rho=5.666 \mathrm{~g} / \mathrm{cm}^{3}$ ) induced volume shrinkage, which generated cracks along columnar AlFe grain boundaries (Fig. 5(e)). Cracks in the AlFe layer stopped propagating in front of more ductile $\mathrm{AlFe}_{3}$ layer. Although $\mathrm{AlFe}$ was softer and less brittle than $\mathrm{Al}_{13} \mathrm{Fe}_{4}$ and $\mathrm{Al}_{5} \mathrm{Fe}_{2}$ [6,20,21], it still suffered from cracking as shown in Fig. 5(e) because oxygen dissolution and void formation during oxidation assisted cracking, in addition to phase transformation and mismatch in thermal expansion coefficients among Al-Fe phases. Since oxygen diffused easily through cracks, oxide particles formed down to the $\mathrm{AlFe} / \mathrm{AlFe}_{3}$ interface (see oxygen map in Fig. 5(g)). From spot 2 to spot 20, the concentration of inwardly diffusing oxygen gradually decreased from $3.2 \%$ to $1 \%$ while $\mathrm{Cr}$ content gradually increased 

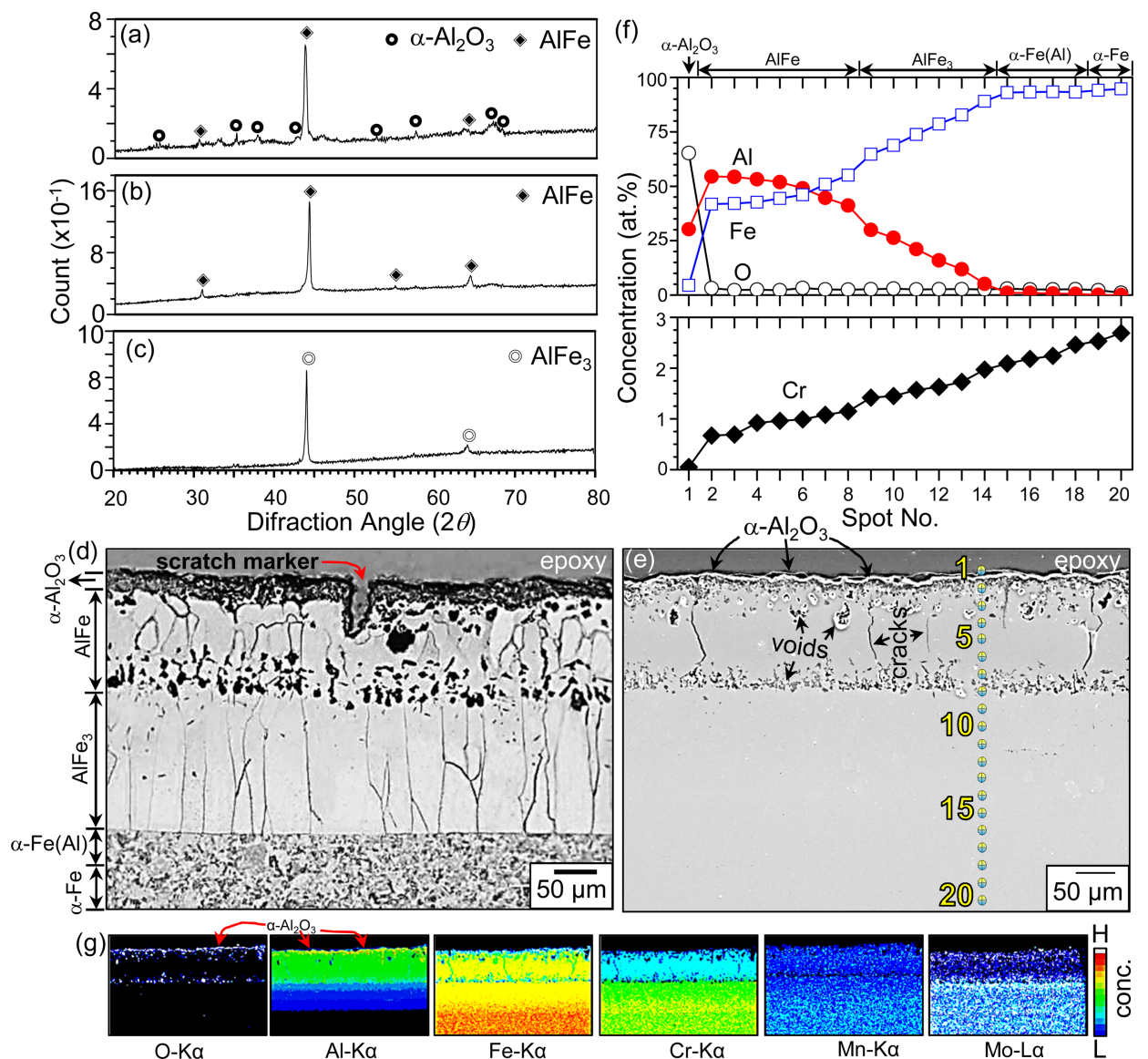

Fig. 5. Hot-dip aluminized $\mathrm{P} 22$ steel after oxidation at $900{ }^{\circ} \mathrm{C}$ for $20 \mathrm{~h}$. (a) XRD pattern before grinding, (b) XRD pattern after first grinding, (c) XRD pattern after second grinding, (d) OM image (etched), (e) EPMA cross-sectional SE image (unetched), (f) SEM-EDS concentration profiles of spots 1-20 shown in (e), (g) EPMA maps of (d).

from $0.6 \%$ to $2.7 \%$ (Fig. 5(f)). Aluminum diffused inwardly and all substrate elements diffused outwardly according to concentration gradients (Fig. 5(g)). Unequal mass flow was responsible for the formation of Kirkendall voids, particularly in the AlFe layer (Fig. 5(e)). The $\alpha-\mathrm{Al}_{2} \mathrm{O}_{3}$ scale was $\sim 25 \mu \mathrm{m}$-thick. It was convoluted to relieve the residual stress accumulated during oxidation (Fig. 5(e)). It was dissolved with $4.4 \% \mathrm{Fe}$ according to the EDS analysis (spot 1 in Fig. 5(f)). This would favor alumina growth and stress accumulation [26]. Dark dots scattered inside spots 1-3 (width $=\sim 45 \mu \mathrm{m}$ ) were $\alpha-\mathrm{Al}_{2} \mathrm{O}_{3}$ particles embedded in the AlFe layer (Fig. 5(e)). The AlFe layer (spots 2-8) was $\sim 120 \mu \mathrm{m}$-thick. It had voids and vertical cracks (Figs. 5(e-f)). The ductile $\mathrm{AlFe}_{3}$ layer (spots 8-14) and $\alpha-\mathrm{Fe}(\mathrm{Al})$ layer (spots 15-18) were $\sim 160$ and $\sim 45 \mu \mathrm{m}$ thick, respectively (Figs. 5(e-f)). Spots 19-20 belonged to $\alpha-\mathrm{Fe}$ substrate (Figs. 5(e-f)). Average compositions of $\mathrm{AlFe}$ layer, $\mathrm{AlFe}_{3}$ layer, and $\alpha-\mathrm{Fe}(\mathrm{Al})$ layer were 49.7Al-46.3Fe-0.9Cr-0.4Mn-2.7O, $18.4 \mathrm{Al}-76.3 \mathrm{Fe}-1.6 \mathrm{Cr}-$ $0.7 \mathrm{Mn}-0.2 \mathrm{~V}-2.8 \mathrm{O}$, and $0.9 \mathrm{Al}-93.3 \mathrm{Fe}-2.2 \mathrm{Cr}-0.7 \mathrm{Mn}-0.2 \mathrm{~V}-$ $2.7 \mathrm{O}$, respectively, according to SEM-EDS analysis. Such results were attributed to interdiffusion of $\mathrm{Al}$, substrate elements, and oxygen during oxidation.

Figure 6 shows XRD/EPMA/EDS/OM results of hotdip aluminized P22 steel after oxidation at $1000{ }^{\circ} \mathrm{C}$ for $20 \mathrm{~h}$. Strong $\alpha-\mathrm{Al}_{2} \mathrm{O}_{3}$ and $\mathrm{AlFe}_{3}$ peaks and weak $\mathrm{Fe}_{2} \mathrm{O}_{3}$ peaks were detected in Fig. 6(a). However, only strong $\alpha-\mathrm{Fe}(\mathrm{Al})$ peaks were detected in Fig. 6(b). Such results indicated the formation of $\alpha-\mathrm{Al}_{2} \mathrm{O}_{3}$-rich scale containing a small amount of $\mathrm{Fe}_{2} \mathrm{O}_{3}$ on the coating that primarily consisted of the $\mathrm{AlFe}_{3}$ outer layer and the $\alpha-\mathrm{Fe}(\mathrm{Al})$ inner layer. In Figs. 6(c-d), spot 1 corresponded to $\alpha-\mathrm{Al}_{2} \mathrm{O}_{3}$ surface scale. Spot 2 

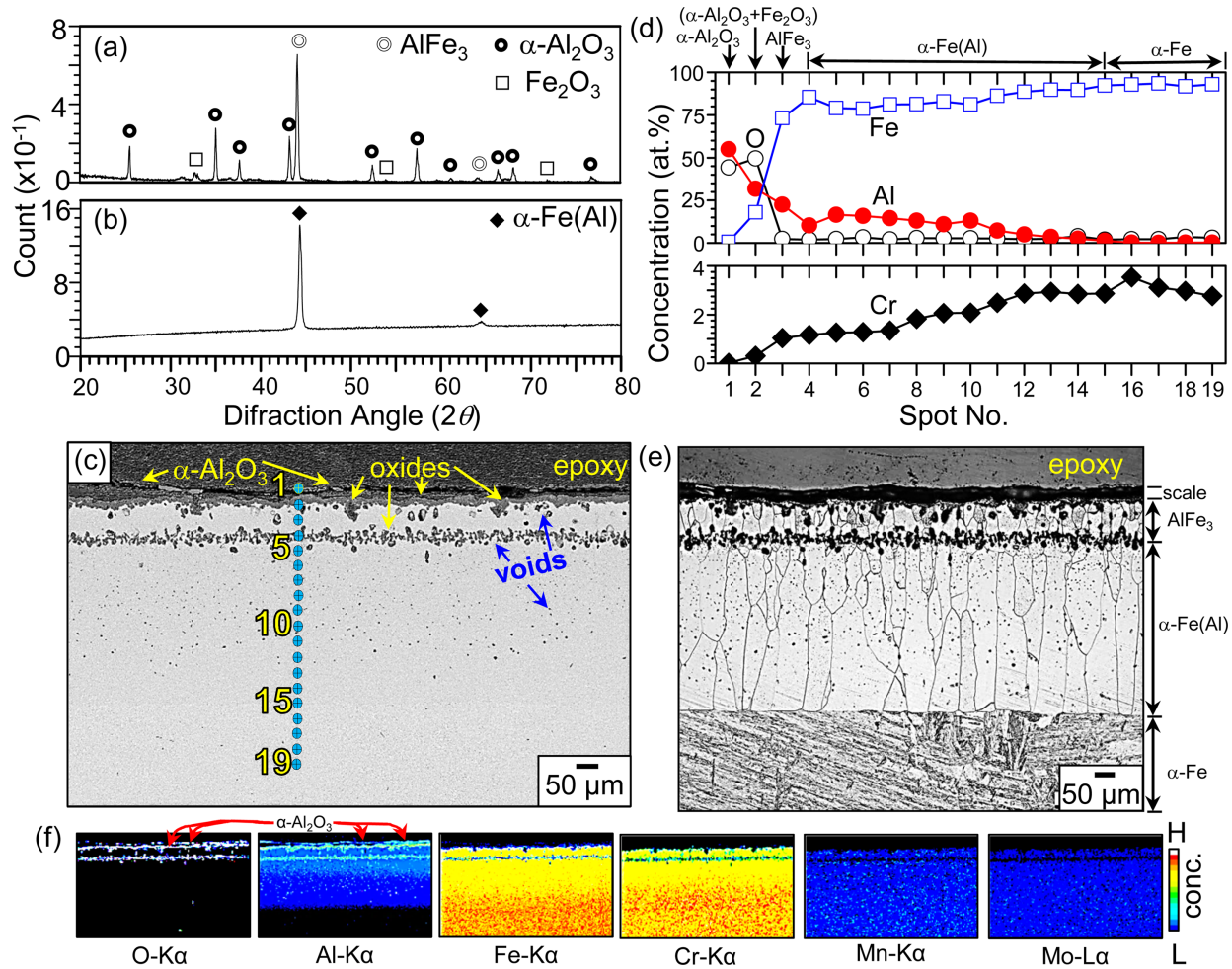

Fig. 6. Hot-dip aluminized $\mathrm{P} 22$ steel after oxidation at $1000^{\circ} \mathrm{C}$ for $20 \mathrm{~h}$. (a) XRD pattern before grinding, (b) XRD pattern after grinding, (c) EPMA cross-sectional SE image (unetched), (d) SEM-EDS concentration profiles of spots 1-19 shown in (c), (e) OM image (etched), (f) EPMA maps of (e).

corresponded to $\alpha-\mathrm{Al}_{2} \mathrm{O}_{3}$-rich scale containing a small amount of $\mathrm{Fe}_{2} \mathrm{O}_{3}$ which was not identified in Fig. 5(a) due to its small amount. Spots 3-4 corresponded to the $\mathrm{AlFe}_{3}$ layer. The composition of spot 3 was 22.5Al-73.3Fe-1Cr-0.6Mn-0.2 $-2.4 \mathrm{O}$ (\%), implying the dissolution of oxygen and some substrate elements. Spots 4-15 corresponded to the $\alpha$-Fe(Al) layer whose average composition was $84.4 \mathrm{Fe}-9.5 \mathrm{Al}-2.2 \mathrm{Cr}-0.6 \mathrm{Mn}-$ $0.3 \mathrm{Si}-0.2 \mathrm{~V}-2.8 \mathrm{O}(\%)$, implying the dissolution of $\mathrm{Al}$, $\mathrm{Cr}, \mathrm{Mn}, \mathrm{Si}, \mathrm{V}$, and oxygen in the $\alpha-\mathrm{Fe}(\mathrm{Al})$ layer. Spots 15-19 corresponded to the $\alpha-\mathrm{Fe}$ substrate whose average composition was $92.8 \mathrm{Fe}-0.2 \mathrm{Al}-3.1 \mathrm{Cr}-0.5 \mathrm{Mn}-$ $0.3 \mathrm{Si}-0.3 \mathrm{~V}-2.8 \mathrm{O}(\%)$, implying that a small amount of $\mathrm{Al}$ and oxygen diffused inwardly into the $\alpha-\mathrm{Fe}$ substrate. Internal oxides and voids in the $\mathrm{AlFe}_{3}$ layer were coarser than those in the $\alpha-\mathrm{Fe}(\mathrm{Al})$ layer because more oxygen was available. Aluminum in the $\mathrm{AlFe}_{3}$ layer diffused inwardly to form the thick $\alpha-\mathrm{Fe}(\mathrm{Al})$ layer and outwardly to form the $\alpha-\mathrm{Al}_{2} \mathrm{O}_{3}$ surface scale to a meager amount (Figs. 6(c) and (e)). Figure 6(e) indicated that $\alpha-\mathrm{Fe}(\mathrm{Al})$ grains were coarser and more columnar than $\mathrm{AlFe}_{3}$ grains, suggesting that interdiffusion along the growth direction occurred faster in the $\alpha-\mathrm{Fe}(\mathrm{Al})$ layer than the $\mathrm{AlFe}_{3}$ layer. Coating phases identified in Fig. 5 ( $900{ }^{\circ} \mathrm{C}$-oxidation) changed in Fig. 6 (1000 ${ }^{\circ} \mathrm{C}$-oxidation) as follows: (1) $\alpha-\mathrm{Al}_{2} \mathrm{O}_{3}-$ rich surface scale (thickness, $\delta=25 \mu \mathrm{m}$, fine grains.) $\rightarrow\left(\alpha-\mathrm{Al}_{2} \mathrm{O}_{3}, \quad \mathrm{Fe}_{2} \mathrm{O}_{3}\right)$-mixed surface scale $(\delta=45 \mu \mathrm{m}$, fine grains); (2) AlFe layer $(\delta=120 \mu \mathrm{m}$, short columnar grains $) \rightarrow \mathrm{AlFe}_{3}$ layer $(\delta=120 \mu \mathrm{m}$, short columnar grains); and (3) $\mathrm{AlFe}_{3}$ layer $(\delta=160 \mu \mathrm{m}$, coarse columnar grains) $\rightarrow \alpha-\mathrm{Fe}(\mathrm{Al})$ layer $(\delta=450 \mu \mathrm{m}$, coarse columnar grains). EPMA maps shown in Fig. 6(f) also confirmed the dissolution of oxygen and substrate alloying elements such as $\mathrm{Cr}, \mathrm{Mn}$, and $\mathrm{Mo}$ in the $\mathrm{AlFe}_{3}$ layer (spot 3-4) and $\alpha-\mathrm{Fe}(\mathrm{Al})$ layer (spots 4-15) besides interdiffusion of $\mathrm{O}, \mathrm{Al}$, and substrate elements.

\section{CONCLUSIONS}

Microstructural change of hot-dip aluminized $2.25 \mathrm{Cr}-$ $1 \%$ Mo steel during oxidation is graphically summarized 


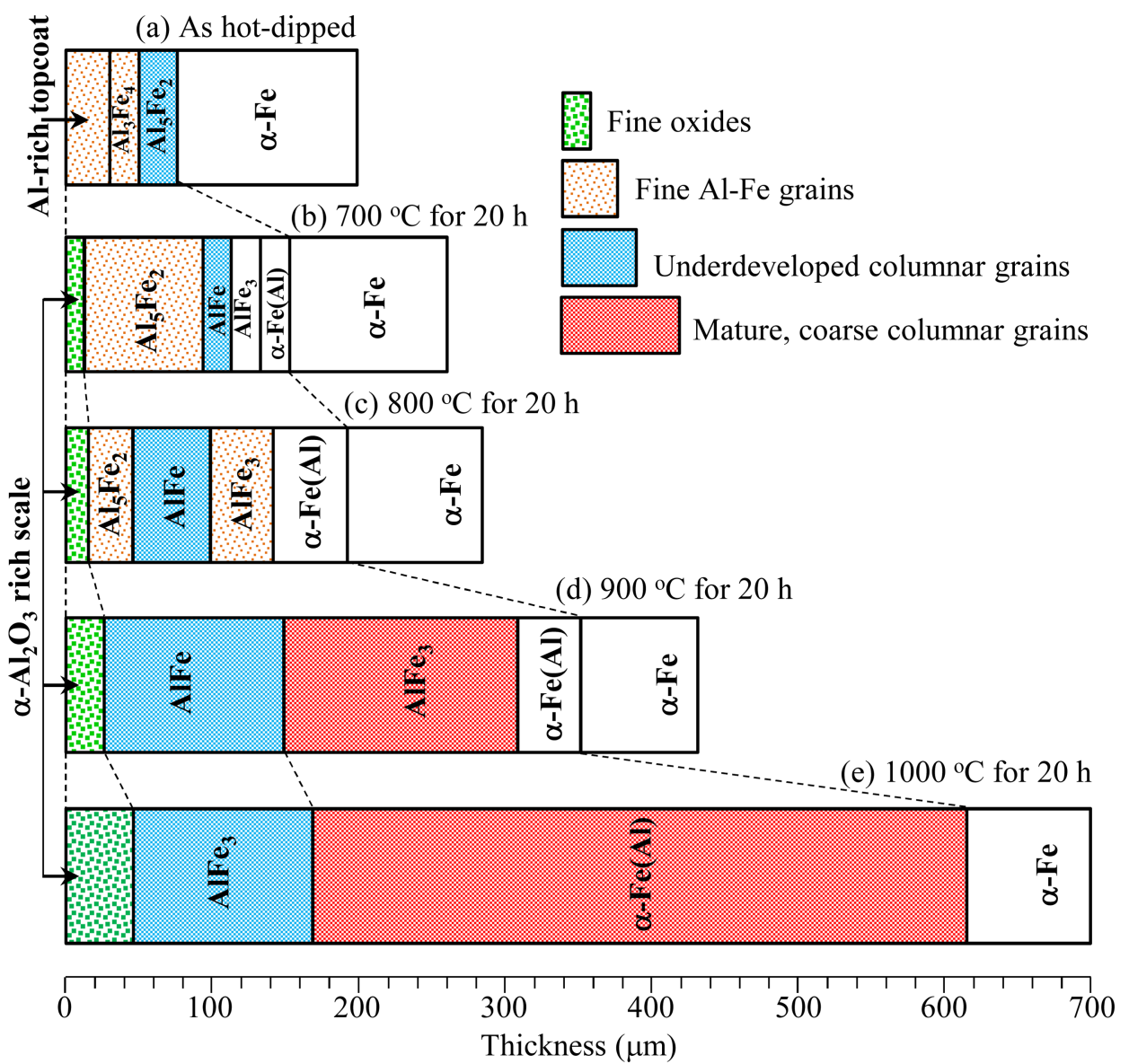

Fig. 7. Schematic diagram showing the phase transition and coating thickness variation of hot-dip aluminized $\mathrm{P} 22$ steel. (a) before oxidation, and after oxidation for $20 \mathrm{~h}$ at (b) $700{ }^{\circ} \mathrm{C}$, (c) $800{ }^{\circ} \mathrm{C}$, (d) $900{ }^{\circ} \mathrm{C}$, and (e) $1000{ }^{\circ} \mathrm{C}$.

in Fig. 7. Hot-dip aluminizing produced $(30 \mu \mathrm{m}$-thick Al-rich topcoat $) /\left(15 \mu \mathrm{m}\right.$-thick $\mathrm{Al}_{13} \mathrm{Fe}_{4}$ layer $) /(20 \mu \mathrm{m}$-thick $\mathrm{Al}_{5} \mathrm{Fe}_{2}$ layer) on the $\alpha-\mathrm{Fe}$ substrate. The $\mathrm{Al}_{5} \mathrm{Fe}_{2}$ layer partly consisted of columnar grains aligned along the interdiffusion direction of $\mathrm{Al}$ and substrate elements while other layers mainly consisted of rather equiaxed grains. Oxidation at $700{ }^{\circ} \mathrm{C}$ for $20 \mathrm{~h}$ produced $(15 \mu \mathrm{m}$ thick $\alpha-\mathrm{Al}_{2} \mathrm{O}_{3}$-rich oxide layer $) /\left(80 \mu \mathrm{m}\right.$-thick $\mathrm{Al}_{5} \mathrm{Fe}_{2}$ layer with a small amount of $\mathrm{Al}_{13} \mathrm{Fe}_{4}$ at its upper part $) /(20 \mu \mathrm{m}$-thick AlFe layer $) /\left(20 \mu \mathrm{m}\right.$-thick $\mathrm{AlFe}_{3}$ layer $) /$ (30 $\mu$ m-thick $\alpha-\mathrm{Fe}(\mathrm{Al})$ layer) on the $\alpha$-Fe substrate. Here, the AlFe layer consisted of short or underdeveloped columnar grains while other layers consisted of fine grains. Oxidation at $800{ }^{\circ} \mathrm{C}$ for $20 \mathrm{~h}$ produced $(17 \mu \mathrm{m}$ thick $\alpha-\mathrm{Al}_{2} \mathrm{O}_{3}$-rich oxide layer $) /\left(25 \mu \mathrm{m}\right.$-thick $\mathrm{Al}_{5} \mathrm{Fe}_{2}$ layer without $\left.\mathrm{Al}_{13} \mathrm{Fe}_{4}\right) /(45 \mu \mathrm{m}$-thick $\mathrm{AlFe}$ layer $) /(45 \mu \mathrm{m}$ thick $\mathrm{AlFe}_{3}$ layer $) /(40 \mu$ m-thick $\alpha$-Fe(Al) layer $)$ on the
$\alpha-\mathrm{Fe}$ substrate. Here, the AlFe layer consisted of short columnar grains while other layers consisted of fine grains. Oxidation at $900{ }^{\circ} \mathrm{C}$ for $20 \mathrm{~h}$ produced $(25 \mu \mathrm{m}$ thick $\alpha-\mathrm{Al}_{2} \mathrm{O}_{3}$-rich oxide layer $) /(120 \mu \mathrm{m}$-thick $\mathrm{AlFe}$ layer $) /\left(160 \mu\right.$ m-thick $\mathrm{AlFe}_{3}$ layer $) /(45 \mu \mathrm{m}$-thick $\alpha$-Fe(Al) layer) on the $\alpha$-Fe substrate. Here, grains of the $\mathrm{AlFe}_{3}$ layer were coarser and more columnar than those of the AlFe layer. Oxidation at $1000{ }^{\circ} \mathrm{C}$ for $20 \mathrm{~h}$ produced $\left(45 \mu \mathrm{m}\right.$-thick $\alpha-\mathrm{Al}_{2} \mathrm{O}_{3}$-rich oxide layer $) /(120$ $\mu$-thick $\mathrm{AlFe}_{3}$ layer $) /(450 \mu$ m-thick $\alpha-\mathrm{Fe}(\mathrm{Al})$ layer $)$ on the $\alpha$-Fe substrate. The transition of the AlFe layer to the $\mathrm{AlFe}_{3}$ layer as well as the $\left(\mathrm{AlFe}_{3}\right.$ layer $) /(\alpha-\mathrm{Fe}(\mathrm{Al})$ layer) to the $\alpha-\mathrm{Fe}(\mathrm{Al})$ layer owing to enhanced interdiffusion of $\mathrm{Al}$ and $\mathrm{Fe}$ was noticeable when the oxidation temperature was increased from 900 to $1000{ }^{\circ} \mathrm{C}$. 


\section{ACKNOWLEDGEMENT}

This research was supported by Basic Science Research Program through the National Research Foundation of Korea (NRF) funded by the Ministry of Education (2017R1D1A1B03028792).

\section{REFERENCES}

1. M. S. Kwon and C. Y. Kang, Korean J. Met. Mater. 54, 40 (2016).

2. M. A. Abro and D. B. Lee, Met. Mater. Int. 23, 92 (2017).

3. B. Lemmens, H. Springer, I. De Graeve, J. De Strycker, D. Raabe, and K. Verbeken, Surf. Coat. Technol. 319, 104 (2017).

4. A. Van Alboom, B. Lemmens, B. Breitbach, E. De Grave, S. Cottenier, and K. Verbeken, Surf. Coat. Technol. 324, 419 (2017).

5. W. J. Cheng and C. J. Wang, App. Surf. Sci. 277, 139 (2013).

6. Q. Y. Zhang, Y. Zhou, J. Q. Liu, K. M. Chen, J. G. Mo, X. H. Cui, and S. Q. Wang, Wear 344, 22 (2015).

7. J. Chen, X. Li, P. Hua, C. Wang, K. Chen, Y. Wu, and W. Zhou, Fusion Eng. Des. 125, 57 (2017).

8. R. A. Jeshvaghani, M. Emami, O. Shafiee, and H. R. Shahverdi, Surf. Coat. Technol. 240, 365 (2014).

9. Z. Shi, J. Cao, and F. Han, J. Nucl. Mater. 447, 77 (2014).

10. M. A. Abro and D. B. Lee, Coatings 7, 31 (2017).

11. J. H. Kim, S. Y. Kim, and C. Y. Kang, Surf. Coat. Technol. 240, 387 (2014).

12. E. Frutos, P. Adeva, J. L. González-Carrasco, and P. Pérez,
Surf. Coat. Technol. 236, 188 (2013).

13. K. Stein-Fechner, J. Konys, and O. Wedemeyer, J. Nucl. Mater. 249, 33 (1997).

14. W. J. Cheng and C. J. Wang, Surf. Coat. Technol. 204, 824 (2009).

15. I. D. Graeve, I. Schoukens, A. Lanzutti, F. Andreatta, A. Alvarez-Pampliega, J. De Strycker, L. Fedrizzi, and H. Terryn, Corros. Sci. 76, 325 (2013).

16. Y. Sun, J. Dong, P. Zhao, and B. Dou, Surf. Coat. Technol. 330, 234 (2017).

17. R. Riedel, Handbook of Ceramic Hard Materials, p.986, Wiley-VCH, Germany (2000).

18. Q. Wang, X. S. Leng, T. H. Yang, and J. C. Yan, Trans. Nonferrous Met. Soc. China 24, 279 (2014).

19. C. Boulesteix and F. Pedraza, Surf. Coat. Technol. 327, 9 (2017).

20. M. J. Rathod and M. Kutsuna, J. Weld. 83, 16s (2004).

21. C. G. McKamey, Physical Metallurgy and Processing of Intermetallic Compounds (eds. N. S. Stoloff and V. K. Sikka), p.351, Springer, USA (1996).

22. M. Emani, H. R. Shahverdi, S. Hayashi, and M. J. Torkamany, Metall. Mater. Trans. A 44, 3176 (2013).

23. S. Kobayashi and T. Yakou, Mater. Sci. Eng. A 338, 44 (2002).

24. H. Mehrer, Diffus. Found. 2, 1 (2014).

25. H. Mehrer, M. Luckabauer, W. Sprengel, Defect Diffus Forum 333, 1 (2013).

26. S. Y. Park, D. Y. Seo, S. W. Kim, S. E. Kim, J. K. Hong, and D. B. Lee, Intermetallics 74, 8 (2016). 